\title{
Application of Life Cycle Assessment (LCA) in Sugar Industries
}

\author{
Arieyanti Dwi Astuti ${ }^{1}$, Rahayu Siwi Dwi Astuti ${ }^{1}$,Hadiyanto Hadiyanto ${ }^{1,2}$ \\ ${ }^{1}$ Master Program of Environmental Science, School of Postgraduate Studies Diponegoro University, Semarang - Indonesia \\ ${ }^{2}$ Chemical Engineering Department, Faculty of Engineering Diponegoro University, Semarang - Indonesia
}

\begin{abstract}
Sugar is one of the main commodities that are needed for human life. The demand of sugar is very high with the trend increase from year to year. This condition makes the sugar industry become a leading industry that must be maintained sustainability. The sustainability of the sugar industry is influenced by the use of energy and natural resources and the resulting environmental impacts. Therefore, an effort is needed to analyze the environmental aspects and potential environmental impacts resulting from a product (sugar), by using Life Cycle Assessment (LCA). LCA is a very important tool for the analysis of a process/system from its cradle to grave. This technique is very useful in the estimation of energy usage and environmental load of a product/system. This paper aims to describe the main elements of sugar industries using Life Cycle Assessment.
\end{abstract}

\section{Introduction}

The sugar industry is one of the vital industries whose existence is needed to meet the basic needs of the community for sugar, making this industry must have a sustainability (sustainability industry). In fact, it is found that the large volume of sugar entering Indonesia through imported faucets as a concrete step of Government policy indicates that the domestic sugar industry has not been able to meet the national sugar demand. In fact, Indonesia's sugar industry is actually able to meet the national sugar demand from the potential of agro-ecosystem owned. The sugar industry is one of the industries considered as economic assets as well as social assets. This is based on the consideration that the prospect of sugar market in Indonesia is quite promising that the consumption of sugar is 4.2-4.7 million tonnes/year [1]. From the social aspect, the sugar industry is able to provide a source of income for 900 thousand sugar cane farmers [2].

The rush of imported sugar is exacerbated by the high cost of producing sugar industry when compared to production cost of other basic products [3], making sugar industry sustainability highly vulnerable. The sustainability of the sugar industry in general is also strongly influenced by the use of energy and natural resources and the resulting environmental impacts in its production process.

Therefore, an effort must be made by the sugar industry in order to achieve efficiency in the production process (sugar production) in order to support the achievement of sustainability industry. The efficiency of a production can be achieved by managing the main elements in the process of producing sugar, which includes the reduction of electricity consumption, energy and natural resources in a single product life cycle. There are various techniques that can be done one of them Life Cycle Assessment (LCA). This technique include maximizing output with the same inputs, reducing raw material and transportation use, the implementation of pollution control, emission reduction in the environment and waste utilization [4]. The aim of this study is to describe the main elements in a sugar industries system using Life Cycle Assessment (LCA).

\section{Life Cycle Assessment (LCA)}

LCA is a tool used to analyze the interaction between human activity and the environment [5]. LCA is an important and comprehensive method for analyzing the environmental impact of a single product or service. One of the things that determine whether or not an efficient production process, can be seen from the using of energy in the production system. Efficient system optimization can generate significant energy and cost savings while minimizing $\mathrm{CO}_{2}$ emissions. LCA scan be carried out with life cycle approaches and can be used for carbon accounting and to evaluate other important environmental impacts such as acidification, ozone depletion, eutrophication, smoke, and health effects on humans [6].

There are five key stages in the life cycle of a product (Figure 1):

- Raw Materials, sourcing the materials required for the product

- Production, converting raw material the products

- Distribution, getting the product to the end user

- Use, where the user derives the direct value from the product

Corresponding author: ariey_antik@yahoo.com 
- End of life, what happens when the end user has finished the product.

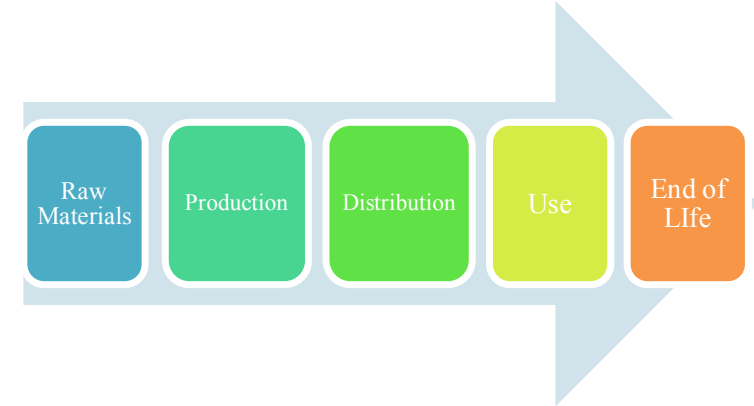

Fig. 1. Stages in The Life Cycle of a Product [7]

The methodological framework for LCA consists of four phases are definition of goal and scope, inventory analysis, impact assessment and interpretation of results as shown in Figure 2 [8].

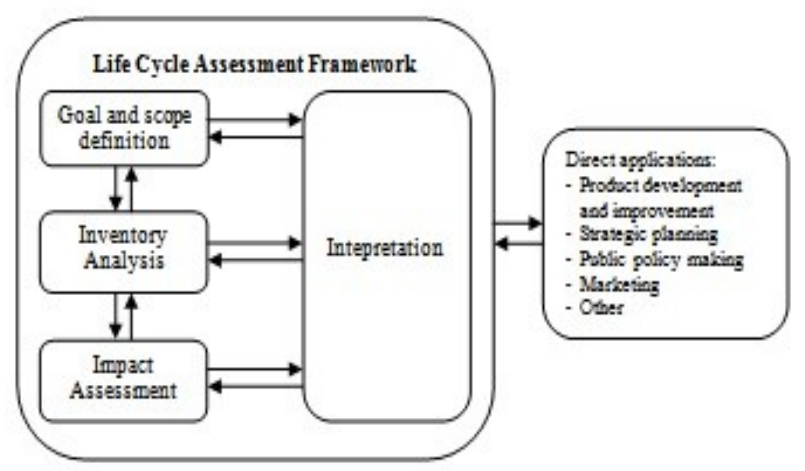

Fig. 2. The Methodological framework for LCA

\section{Sugar Producing Materials}

Sugar is one of the basic needs in the fulfillment of human life. Generally, sugars are produced from sugar cane crops found in tropical climates. In addition to sugarcane, sugar can also be produced from corn, beet, cassava and so on [9]. However, in some countries, sugar cane becomes the mainstay raw material in the production of sugar due to several reasons, such as several aspects as considered as over all cost, environmental effects, rate of sugar production and percentage of sucrose present in different materials [10].

\section{Sugar Industries}

In earlier time, the sugar industry only produced the main products of white sugar. But nowadays, besides producing sugar, sugar industries also produce other products such as cogeneration energy of bagasse, and ethanol. In general, the process of production in the sugar industry includes several main process, including the process of milling, clarification, crystallization and centrifugation [11].

\subsection{Sugar milling}

Initially, sugarcane is washed to remove excessive quantity of soil, rocks, and trash. After cleaning and fibrising of sugarcane, it passes through several types of mill to get extract raw juice of sugar cane. This sugar cane contains sucrose as the main ingredient of sugar making. Before milling, sugar cane will be crushed first which aim to simplify the process of sugar cane extraction. This process will produce two types of products namely bagasse and sugar cane extract. Both products are separated in different places, baggase used for energy cogeneration raw materials, while sugar cane extract is transferred to the next process, juice clarification and treatment.

\subsection{Clarification}

In this process, raw juice will be treated with the addition of chemicals such as sulfur $\left(\mathrm{SO}_{2}\right)$ and lime. The addition of this chemical aims to coagulate the impurities contained in the juice so easily deposited to be separated [11]. The chemical reactions of these chemicals will separate the juice into 2 parts, in liquid form (syrup), and in solid form (mud or filter cake) [4].

\subsection{Crystallization}

The syrup from the clarification process is then evaporate using heat. The purpose of this evaporation is to remove the water content so that it will be obtained thick syrup and ultimately produce massecuite that is the solution mixture of crystals of sugar and molasses.

\subsection{Centrifugal separation}

After crystallization, massecuite is passed through centrifugal tanks. These tanks are used to separate sugar and molasses. Molasse is the remaining massecuite that no longer contains sugar crystals. Sugar that comes out from these tanks are passed though vibrating device that addition serve as a means of transport also serves as a dryer. After drying, sugar is ready to be packed.

\section{LCA of Sugar Industries}

LCA in sugar industry has been done in many sugar producing countries. The LCA has different results depending on the system boundary, goal, inventory result and selected impact analysis (Figure 1). Research related to LCA aims to improve the balance of energy in sugar industry. This can be done by reducing the amount of water use, using steam in heating raw juice, using electricity from the use of baggase and heating raw juice by condensation. Analysis LCA in the sugar industry in Australia is able to contribute significantly to the environmental impact [10]. LCA study of sugar industry for different countries is shown in Table 1. 
Table 1. Result of LCA Study in Sugar Industries

\begin{tabular}{|c|c|c|c|c|c|}
\hline No & Author & System Boundary & $\begin{array}{c}\text { Functional } \\
\text { Unit }\end{array}$ & Input & Output \\
\hline 1 & $\begin{array}{l}\text { Toolseram } \\
\text { Ramjeawon(12) }\end{array}$ & $\begin{array}{l}\text { Cane production and } \\
\text { harvest, cane burning, } \\
\text { transportation, fertilizer and } \\
\text { herbicide manufacture, and } \\
\text { sugar processing, electricity } \\
\text { generation }\end{array}$ & $\begin{array}{l}1 \text { tonne of } \\
\text { raw cane } \\
\text { sugar }\end{array}$ & $\begin{array}{ll}\text { - } & \text { Land, } 0.12 \mathrm{ha} \\
\text { - } & \text { Water, } 553 \mathrm{~m}^{3} \\
\text { - } & \text { Fossil fuel, } 1995 \mathrm{MJ} \\
\text { - } & \text { Total energy (fossil fuel } \\
& \text { and baggase), } 14235 \\
& \text { MJ }\end{array}$ & 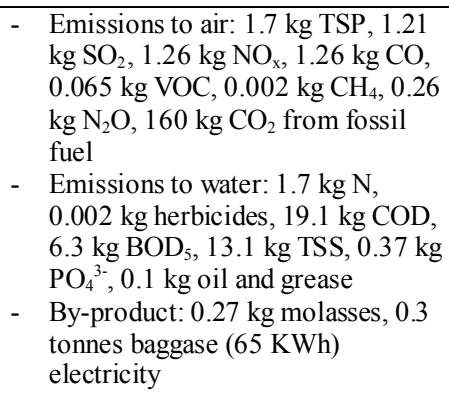 \\
\hline 2 & $\begin{array}{l}\text { Livision } \\
\text { Mashoko, } \\
\text { Charles } \\
\text { Mbohwa, and } \\
\text { Valerie M. } \\
\text { Thomas(13) }\end{array}$ & $\begin{array}{l}\text { The growing and harvesting } \\
\text { of sugar cane all the way to } \\
\text { the production of sugar and } \\
\text { co-generation of electricity } \\
\text { from baggase }\end{array}$ & $\begin{array}{l}1 \text { tonne of } \\
\text { raw cane } \\
\text { sugar }\end{array}$ & $\begin{array}{ll}\text { - } & 846 \text { tonnes of cane } \\
\text { - } & \text { Total fossil energy } 1893 \\
\text { MJ/tonne of raw sugar } \\
\text { produce } \\
\text { - } \quad \text { Coal, } 70.8 \mathrm{~kg}(1397 \\
\mathrm{MJ} / \text { tonne of raw sugar } \\
\text { produced }) \\
\text { - } \quad \text { Water, } 17000 \mathrm{~m}^{3} / \mathrm{ha} \\
\text { - } \quad \text { Land, } 0.15 \mathrm{ha}\end{array}$ & $\begin{array}{l}\text { - } 35 \mathrm{KWh} \text { of electricity from } 1 \text { tonne } \\
\text { of cane crushed } \\
\text { - } \quad \text { Emissions from cane burning : } 280 \\
\mathrm{~kg} \text { of tops and dry leavesat } 50 \% \\
\text { moisture per metric tonne of cane } \\
\text { harvested } \\
\text { - } \quad \text { Ashes and slags, } 368 \mathrm{~kg} / \text { tonne } \\
\text { sugar } \\
\text { - } \quad \text { Emissions to air : } 7.5 \mathrm{~kg} \mathrm{CH}_{4}, 196 \\
\mathrm{~kg} \mathrm{CO}_{2}, 0.5 \mathrm{~kg} \mathrm{~N}_{2} \mathrm{O}, 2.18 \mathrm{~kg} \mathrm{SO}_{2}, \\
7.5 \mathrm{~kg} \mathrm{NO}, 0.85 \mathrm{~kg} \text { suspended } \\
\text { particulate matter } \\
\text { - Emissions to water : } 6.6 \mathrm{~kg} \mathrm{BOD}_{5}, \\
19 \mathrm{~kg} \mathrm{COD}, 12 \mathrm{~kg} \mathrm{NO}_{3}^{-}, 0.15 \mathrm{~kg} \\
\mathrm{PO}_{4}^{3-}, 0.05 \mathrm{~kg} \text { suspended solids, } \\
0.00126 \mathrm{~kg} \text { Fe } \\
\text { By-Products : } 0.56 \text { tonne filter } \\
\text { cake, } 0.38 \text { tonne molasses }\end{array}$ \\
\hline \multirow[t]{3}{*}{3} & $\begin{array}{l}\text { Wichita } \\
\text { Witayapairot, } \\
\text { and Chatpet } \\
\text { Yossapol(3) }\end{array}$ & $\begin{array}{l}\text { Cane cultivation, sugar } \\
\text { production process, } \\
\text { electricity production, } \\
\text { ethanol production }\end{array}$ & $\begin{array}{l}1 \text { tonne of } \\
\text { cane }\end{array}$ & $\begin{array}{ll}\text { Cane cultivation (1 tonne): } \\
\text { - } & \text { Cane seed, } 136.74 \mathrm{~kg} \\
\text { - } & \text { Water } 138.1 \mathrm{~m}^{3} \\
\text { - } & \text { Fertilizer } 11.39 \mathrm{~kg} \\
\text { - } & \text { Herbicide } 0.18 \mathrm{~kg} \\
\text { - } & \text { Diesel } 3.26 \mathrm{~L}\end{array}$ & $\begin{array}{l}\text { Cane cultivation: } \\
\text { - Cane, } 1 \text { tonne } \\
\text { - } \quad \text { Emission to air : } 9.7 \mathrm{~kg} \mathrm{CO}_{2}, 3.8 \mathrm{~kg} \\
\mathrm{CO}, 0.9 \mathrm{~kg} \mathrm{NO}, 0.4 \mathrm{~kg} \mathrm{SO}_{2}, 0.114 \\
\mathrm{~kg} \mathrm{SPM} \\
\text { - } \quad \text { Emission to soil : } 0.11 \mathrm{~kg} \mathrm{~N}_{2} \mathrm{O}, \\
0.38 \mathrm{~kg} \text { nitrogen, } 0.042 \mathrm{~kg} \mathrm{BOD}, \\
0.0073 \mathrm{~kg} \text { Phosphorus }\end{array}$ \\
\hline & & & & $\begin{array}{l}\text { Sugar Production : } \\
\text { - } \quad \text { Cane, } 1 \text { tonne } \\
\text { - } \quad \text { Lime } 1.5 \mathrm{~kg} \\
\text { - } \quad \text { Flocculants } 6.54 \mathrm{~kg} \\
\text { - } \quad \text { NaOH } 0.43 \mathrm{~kg} \\
\text { - } \quad \text { Water } 0.046 \mathrm{~m}^{3} \\
\\
\text { Electricity Production : } \\
\text { - } \quad \text { Baggase, } 280 \mathrm{~kg} \\
\text { - } \quad \text { Water, } 112.71 \mathrm{~kg} \\
-\quad \text { Diesel, } 4.85 \mathrm{~L}\end{array}$ & $\begin{array}{l}\text { Sugar Production : } \\
\text { - } \quad \text { Raw sugar } 60.02 \mathrm{~kg} \\
\text { - } \quad \text { Refin esugar } 31.71 \mathrm{~kg} \\
\text { - } \quad \text { Super refine sugar } 16.81 \mathrm{~kg} \\
\text { - } \quad \text { Waste water : } 7.65 \times 10^{-3} \mathrm{mg} / 1 \\
\quad \text { BOD, } 3.44 \times 10^{-4} \mathrm{mg} / 1 \text { nitrate, } 6.92 \\
\quad \text { x } 10^{-3} \text { phospate } \\
\text { - } \quad \text { By-Products : } 280 \mathrm{~kg} \text { baggase, } \\
\quad 40.25 \mathrm{~kg} \text { filter cake, } 55 \mathrm{~kg} \\
\quad \text { molasses } \\
\text { Electricity Production : } \\
\text { - } \quad \text { Electricity, } 69.4 \mathrm{KWh}\end{array}$ \\
\hline & & & & 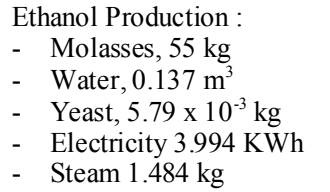 & $\begin{array}{l}\text { Ethanol Production : } \\
\text { - } \quad \text { Ethanol } 99.5 \% \rightarrow 14.47 \mathrm{~L} \\
\text { - } \quad \text { Vinasse } 6.51 \times 10^{-2} \mathrm{~kg}\end{array}$ \\
\hline
\end{tabular}

\section{LCA of by-product Sugar Industries}

Besides producing sugar, the sugar industry also produces several "by-product" such as baggase and molasses which are the raw material for other plants. Baggase is used to source raw materials from power plants, while molasses are used as a source of raw materials for ethanol production. The utilization of these two materials aims to improve the environmental profile of the industry as well as to increase the economic value of the waste. These by products from sugar industries can produce electricity, fuel, paper and organic chemicals[14]. The production of electricity from baggase and trash cane has an important role in reducing $\mathrm{CO}_{2}$ emissions. 


\subsection{Baggase}

As explained earlier that the sugar industries are now using the waste generated, such as baggase used as a raw material for cogeneration energy. Every 100 tons of sugar cane is capable of producing 11.8 tonnes of sugar and 28-30 tonnes of baggase which contain about 50\% water[15]. In South Africa, 1 tonnes of raw sugar produced by 8.46 tonnes of sugarcane, $17.000 \mathrm{~m}^{3}$ of water, 0.15 ha of land and $71 \mathrm{~kg}$ of coal. However, the production process also produces byproducts of 0.56 tonnes of filter cake and 0.38 tonnes of molasses, 2.4 tonnes of baggase and $368 \mathrm{~kg}$ of ashes and slugs. Production of 1 ton of sugar requires $23.800 \mathrm{MJ}$ of renewable and non renewable energy which $18.400 \mathrm{MJ}$ renewable energy is provided from baggase[13]. While the sugar industry in Mauritius, 1 tonnes of sugar can be produced using resources of 0.12 land, $553 \mathrm{~m}^{3}$ of water,1995 MJ fossil fuel, 14.235 MJ total energy consumption (fossil fuel and baggase)[12] In Thailand, 1 tonnes of sugar cane with $4.6 \times 10^{-2} \mathrm{~m}^{3}$ water is able to produce $60.02 \mathrm{~kg}$ raw sugar, $31.71 \mathrm{~kg}$ refine sugar, 16.81 $\mathrm{kg}$ super refined sugar and $55 \mathrm{~kg}$ molasses. By product that produced are $280 \mathrm{~kg}$ baggase and $40.25 \mathrm{~kg}$ of filter cake [3]. From another study, 1 tonnes of sugarcane production requires 0.017 ha of land and produced 103.6 $\mathrm{kg}$ of sugar, $45.2 \mathrm{~kg}$ of molasses, $247 \mathrm{~kg}$ baggase, and $16.94 \mathrm{kWh}$ of electricity[16].

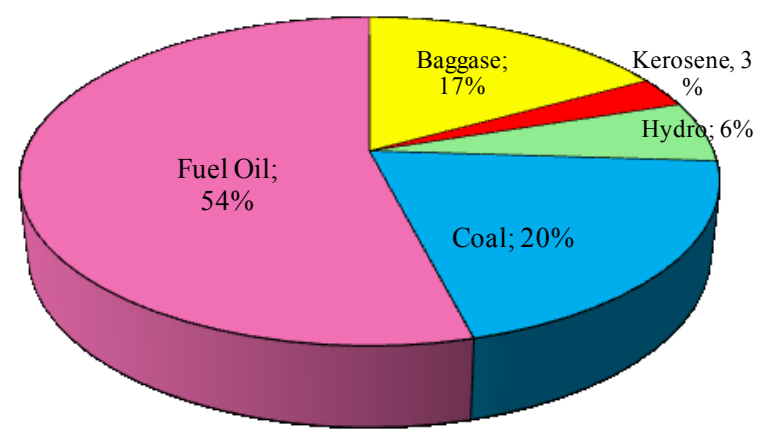

Fig. 3.Resource required of electricity in Mauritius [17]

Baggase is a by-product of the sugar industry used as inputs for power generation sources and capable of meeting industrial electricity needs. Even in some countries are able to supply electricity from the use of baggase for use outside the sugar industry. The fact that the sugarcane plant provides its own source of energy from sugar production in the form of baggase has long been a special feature of the sugar industry. In Mauritius, in traditional approach, sugar industries co-generate just enough steam and electricity to meet their on-site needs. With the availability of advanced co-generation technologies, sugar industries today can produce surplus electricity for sale to the national grid or directly to other electricity users. Such industries burn baggase during the crop season and use coal as a complementary fuel, during the intercrop. Around 44\% (750 GWh) of electricity in Mauritius comes from the sugar industries, of which $21 \%(360 \mathrm{GWh})$ is from baggase. Electricity generated from baggase combustion provides an environmental advantage over electricity generated from fossil fuels (oil and coal)[17]. The use of baggase as a source of raw material for electricity is able to meet $17 \%$ of electricity demand in Mauritius compared to other sources of power, as shown in Figure 3.

\subsection{Molasses}

Molasses is also one of the most economically important by-products of sugar industries which is used as raw material of ethanol generation. Ethanol analysis has been done either directly from sugar cane or indirectly from by product sugar industry, molasses [13]. In a day, molasses produced in the sugar industry $\mathrm{X}$ in Indonesia is $60.000 \mathrm{~kg}$. To produce ethanol, molasses are mixed with $12.000 \mathrm{~kg}$ water/day, $3.000 \mathrm{~kg}$ of $\mathrm{H}_{2} \mathrm{SO}_{4}$ solution per day, Saccahro mycescerevicesiae $1.500 \mathrm{~kg} / \mathrm{day}, 600$ $\mathrm{kg}$ urea per day. Fermentation and distillation process produces $13.413 \mathrm{~kg} /$ day of bioethanol, water vapor $17.020 \mathrm{~kg} /$ day and vinasse 46,667 kg/day[18].

An average of 1 ton sugarcane produces $23 \mathrm{~L}$ of molasses. Molasses have many industrial uses i.e generation of alcohol, preparation of animal feeds, and food stuffs. Molasses containing large fractions of fermentable sugars which is diluted with water and allowed to ferment in the presence of yeast culture either by batch or continuous process of fermentation [19].

\section{Conclusions}

In the past, sugar industries produced only sugar crystal but nowadays sugar industries are involved in the production of sugar, electricity and ethanol. So, sugar industry is now called as the cane industry. From several studies LCA of sugar industries, it can be concluded that the main elements of sugar industries are cane cultivation and harvesting, transportation, fertilizer and herbicide use, sugar production, co-generation of electricity, and ethanol production. Electricity and ethanol are products that generate from by-products of sugar industries, baggase and molasses.

\section{Reference}

1. Direktorat Jenderal Industri Agro dan Kimia. Roadmap Industri Gula. (2009).

2. Togi Y, Marpaung F, Hutagaol P, Limbong WH, Kusnadi N, Belakang L. Indones J Agric Econ.2, 114 (2011).

3. Witayapairot W, Yossapol C. Life Cycle Assessment of Sugar Production in Northeastern Thailand. In: International Conference on Green and Sustainable Innovation. (2009).

4. Chauhan MK, Varun, Chaudhary S, Kumar S, Samar. Renew Sustain Energy Rev.;15(7),34453453 (2011).

5. Kautzar GZ, Sumantri Y, Yuniarti R.. J Manajemen, dan Sist Ind.3(1), 200-211 (2014).

6. Aziz R, Chevakidagarn P, Danteravanich S.. 
Walailak Journal of Science and Technology (WJST) 13(3), 221-33 (2016).

7. H. Lehtinen, A. Saarentaus, J. Rouhiainen, M. Pitts, A. Azapagic. A Review of LCA Methods and Tools and their Sustainability for SMEs.Europe Innova, (2011).

8. ISO 14040. International Standard ISO 14040 Environmental Management - Life Cycle Assessment - Principles and Framework. 1997.

9. Eggleston G, Lima I. Sustain. 77(9), 12209-12235 (2015).

10. Renouf MA, Wegener M. 29th Conf Aust Soc Sugar Cane Technol.29:385-400 (2007).

11. Purwaningsih IW. Penilaian Daur Hidup (Life Cycle Assessment) Gula Tebu di PG Subang, Jawa Barat. Universitas Diponegoro, Semarang; (2016).

12. Ramjeawon T. Int J Life Cycle Assess. 9(4), 254-60
(2004)

13. Mashoko L, Mbohwa C, Thomas VM. Journal of Environmental Planning and Management 53(6), 793-807 (2010).

14. J. M. Paturau. Alternative Uses of Sugarcane and Its By Products in Agroindustries. Available from: http://www.fao.org/livestock/agap/frg/AHPP72/7224.pdf

15. Crop W. South African Sugar Industry. 2012.

16. Nguyen TLT, Gheewala SH. Int J Life Cycle Assess. 13(4),01-11 (2008);

17. Balaji A, Karthikeyan B, Sundar Raj C. J Clean Prod.16(1),1727-34(2008).

18. Putra, A. S . Molekul.8(2),:123-30(2013).

19. Dotaniya ML, Datta SC, Biswas DR, Dotaniya CK, Meena BL, Rajendiran S,. Int J Recycl Org Waste Agric5(3),185-94 (2016) 